\title{
Identifying the causes of low participation rates in Conservation Tenders
}

\author{
Essay to the International Review of Environmental and Resource Economics (IRERE) \\ John Rolfe ${ }^{* 1}$, Steve Schilizzi ${ }^{2}$, Peter Boxall ${ }^{3}$, Uwe Latacz-Lohmann ${ }^{4}$, Sayed \\ Iftekhar', Megan Star ${ }^{1}$, Patrick O'Connor ${ }^{5}$
}

1. School of Business and Law, Central Queensland University, Australia

2. UWA School of Agriculture and Environment, The University of Western Australia, Australia.

3. Department of Resource Economics \& Environmental Sociology, University of Alberta, Canada

4. Department of Agricultural Management and Production Economics, University of Kiel, Germany.

5. Centre for Global Food and Resources, University of Adelaide, Australia.

* Corresponding author: School of Business and Law, Central Queensland University, Rockhampton, Queensland, Australia.E-mail address: j.rolfe@cqu.edu.au.

\begin{abstract}
Conservation tenders are being used as a policy mechanism to deliver environmental benefits through changes in land, water and biodiversity management. While these mechanisms can potentially be more efficient than other agri-environmental and payment for ecosystem service schemes, a key limitation in practice is that participation rates from eligible landholders are often low, limiting both efficiency and effectiveness. In this paper we document and review potential causes of low participation in two categories: those that treat participation as an adoption issue focused on searching for the landholder, farm or practice characteristics that limit participation; and those that treat it as an auction design issue, looking for the different auction, contract or transaction cost elements that limit landholder interest in participation. We then model how landholders make choices to engage and bid in a tender, making three important contributions to the literature on this topic. First, we document the low participation rates in conservation tenders, mostly across developed countries, an issue that has received little attention to date. Second, we explain that a decision to participate in a conservation tender involves three simultaneous decisions about whether to change a management practice, whether to be involved in a public or private program with contractual obligations, and how to set a price or bid. Third, we explain that there are a number of factors that affect each stage of the decision process with some, such as landholder attitudes and risk considerations, relevant to all three. Our findings suggest that decisions to participate in a conservation tender are more complex than simple adoption decisions, involving optimisation challenges over a number of potentially offsetting factors.
\end{abstract}

Keywords: Conservation tenders; reverse auctions; participation; landholders JEL classification: 


\section{INTRODUCTION}

Conservation tenders and similar forms of procurement auctions are increasingly being used as a policy mechanism for contracting landholders and agricultural producers to deliver environmental benefits (Whitten et al., 2013, Whitten et al., 2017, Rolfe et al., 2017). The tender mechanism is essentially a one-sided auction with usually a single buyer and many sellers (hence the term reverse auction), used to contract private landholders to deliver public goods. This is often done by competitively contracting landholders to reserve areas for conservation (e.g. Stoneham et al., 2003), restore or rehabilitate lands for environmental purposes (e.g. Boxall et al., 2017), or change management practices so as to reduce impacts on environmental assets (e.g. Rolfe et al., 2011). Interest in these mechanisms has grown because of their expected efficiency advantages over fixed payment schemes and other approaches, as well as the insights into innovation and price discovery (Latacz-Lohmann and Van der Hamsvoort, 1997, Latacz-Lohmann and Van der Hamsvoort, 1998, Stoneham et al., 2003, LaLatacz-Lohmann and Schilizzi., 2005, Ferraro, 2008, Hanley et al., 2012, Whitten et al., 2017)

Globally there is growing use of different mechanisms such as payment for ecosystem service schemes to incentivise land managers and owners to provide additional environmental outcomes (Wunder et al. 2008, 2018; Salzman et al. 2018). Conservation tenders are one specialised approach within that pool of mechanisms. Tenders have potential to provide substantial efficiency advantages because they employ a competitive mechanism that selects lower cost proposals. In addition they reveal information about the underlying opportunity costs of landholder actions, and constrain the incentives that landholders may have to request higher rents as part of their proposals (LataczLohmann and van der Hamsvoort 1997, 1998; Schilizzi and Latacz-Lohmann 2016; Whitten et al. 2017).

A common feature of many conservation tenders seems to be low participation rates of potential bidders, defined as the ratio of actual bidders to the pool of eligible bidders, with implications on both efficiency and effectiveness ${ }^{1}$ (Windle and Rolfe., 2008, Morrison et al., 2011, DePiper., 2015, Palm-Forster et al., 2016a,b, Motallebi et al., 2016). While low participation rates have also been identified with broader agri-environmental and payment-for-ecosystem service schemes (Defrancesco et al., 2008, Haynes et al., 2007, Mettepenningen et al., 2011, Taylor and Van Grieken, 2015), the comparative rates for conservation tenders appear to be lower (Jack 2013; Palm-Forster et al. 2016a,b). However, participation rates in conservation tenders are often not reported in the literature, meaning that this potential limitation of conservation tenders is largely hidden from view. Since tenders rely on competition among bidders for a limited budget, an implication of low participation is that the efficiency of conservation tenders may be called into question because higher cost projects are more likely to be funded and program budgets may not be fully allocated (Palm-Forster et al. 2016a). Furthermore, even though lower cost proposals may be selected, the tender may be ineffective at achieving desired environmental improvements, leading to efficiency at the cost of low effectiveness.

Thus, low levels of involvement in tenders (and wider agri-environmental schemes) have economic and environmental impacts (Morrison et al., 2011; Whitten et al. 2013; Palm-Forster et al. 2016a,b).

\footnotetext{
${ }^{1}$ Efficiency is defined as the ratio of number of outcome units to the cost of producing them, while costeffectiveness relates outcome to the agency's budgetary outlay. Effectiveness is defined as the units of outcome achieved with or without reference to a specific target (Schilizzi \& Latacz-Lohmann, 2007).
} 
Participation rates are required to be high enough ensure sufficient competition for the limited budgets available, thus avoiding inefficiencies in the selection process, constraining opportunities for strategic behaviour, and ensuring that program targets are met (Ferraro, 2008, Blackmore and Doole, 2013, Doole et al., 2014, Whitten et al., 2013, Whitten et al., 2017, DePiper, 2015, PalmForster et al., 2016a,b, Holzer et al., 2017). Low participation rates make it difficult to identify and select lower cost bids if many low-cost individuals did not participate; they may also allow greater levels of information rent seeking (generating efficiency losses), and make it difficult to allocate program funds wisely to achieve program targets (effectiveness losses) (Iftekhar et al., 2014).

There has been limited attention to examining low participation rates in conservation tenders, or even on identifying what an appropriate approach to measuring participation would be. The sparse literature on participation in tenders is mostly focused on identifying drivers of participation (e.g. Morrison et al., 2011, Whitten et al., 2013), in line with efforts to explain how landholders adopt better management practices (e.g. Pannell et al., 2006) or engage in agri-environmental or payment for ecosystem service schemes (Wunder et al. 2008; Defrancesco et al., 2008, Hynes and Garvey, 2009, Mettepenningen et al., 2011, Mettepenningen et al., 2013, Taylor and Van Grieken, 2015).

However, these approaches may have limited value because adoption decisions and engagement with funding authorities are nested within tender mechanisms, making it difficult to identify whether participation, or the lack of it, is driven by adoption barriers, transaction costs, reluctance to engage with government and funding agencies, or the elements of the tender process, such as design of the auction.

This review makes three important contributions to the literature. First, we review the literature on conservation tenders and highlight that typically there seems to be a systematic problem with low participation levels. Second, we examine the complexity of the adoption decision, where landholders involved in a tender typically have to decide if they will (a) change their management practice, (b) engage in the tender process, and (c) set their price by submitting a bid. In contrast, landholders wishing to improve productivity typically only face choice (a), while those involved in agrienvironmental grant schemes face choices (a) and (b). These joint and/or sequential aspects of decisions about participation have received little attention in the literature. While Ma et al. (2012) apply a two stage model to explain participation in a payment-for-ecosystem services market, we show that when tenders are also involved, a three-stage process is needed. Third, we develop behavioural models of participation that provide a pathway for future testing and analysis.

Our aim in this paper is to re-examine the drivers of participation in conservation tenders and the factors which influence landholders to engage in them across the steps of practice change, engagement and bid formation. Our key contribution to the literature is to explain how choices in conservation tenders differ from simpler adoption and grant scheme decisions, and how this interacts with drivers of participation and cost and outcome uncertainties. The paper is structured into six sections. In the next section we review the literature on participation levels, followed by an analysis of the drivers and barriers to participation. In section four the issues in auction design and performance are reviewed as an alternative way of understanding the barriers to participation. A framework for participation is developed in section five, which helps to distinguish between important factors relevant to adoption decisions, participation in agri-environmental schemes, and participation in conservation tenders. Discussion and conclusions follow in the final section. 


\section{PARTICIPATION RATES IN CONSERVATION TENDERS}

Land-based conservation tenders are typically targeted to a group of eligible landholders, often described as the extent of the market, from which are successively drawn expressions of interest (EOIs), submitted bids and successful bids (Latacz-Lohmann and Van der Hamsvoort, 1997, Hanley et al., 2012, Whitten et al., 2013, Schilizzi and Latacz-Lohmann, 2016). In our definition, we focus on bidders rather than bids in case there is confusion with multiple bids from a single entity, and on active bids rather than EOIs to focus on actions rather than interest. This also distinguishes participation from success, which is the ratio of successful bidders to active bidders or alternatively the ratio of successful bids to submitted bids.

We also note that the requirements for participation depend on the mechanism and the extent and type of the amenity being protected. For example programs that target extensive changes in farming, land management practices or protection of a whole ecosystem may require much higher levels of participation than programs seeking to protect small (or, very targeted) areas of an asset type. Often mechanisms such as education and extension or fixed grant schemes are used for broader targets, in part because they may also have encouragement and information functions, although the Conservation Reserve Program is an example of an auction process in a similar broad setting (Hellerstein, 2017).

To assess participant rates, we reviewed the international literature to build a database of conservation tenders that have been conducted. We focused only on published articles in the literature in an effort to standardise the identification process, even though this means many tenders have not been counted ${ }^{2}$, as it was not feasible to search the grey literature across multiple countries and languages. We also limited our search to conservation tenders that involved farming or agricultural households providing environmental benefits, and focused on actual field tenders rather than simulations or laboratory experiments. The Scopus database was searched using the terms 'conservation tender', 'conservation auction', 'procurement tender' and 'reverse tender', and the relevant papers were identified. Special issues on PES schemes, market based instruments and conservation tenders in Ecological Economics (2008) and Land Use Policy (2013 and 2017) respectively as well as key review articles (Latacz-Lohmann and Schilizzi 2005; Whitten et al. 2017; Wunscher and Wunder 2017; Lundberg et al. 2018) were also checked. Once relevant tenders were identified, other associated articles and grey literature was searched to flesh out additional details (some tenders have supported multiple publications).

The results of the search process appear robust; for example the process identified the same list of conservation tenders in developing countries that are covered in the review by Wunscher and Wunder (2017, as well as the studies by Wang et al. (2012) in China and Pant (2015) in Nepal. Some tenders identified in the literature were not added to the database because not enough detail was available, including four tenders in Australia (Lowell et al. 2007; Zammitt 2013) and one in Finland (Primmer 2017). We excluded studies in some closely related fields, including fish license and vessel buyback schemes (e.g. (Schilizzi and Latacz-Lohmann 2012; DePiper et al 2013), buybacks or transfers of development rights (e.g. Messer 2007; Horowitz et al. 2009; Messer and Allen 2010), commodity auctions with related environmental information (e.g. Bostkovic and Nostbakken 2017), and water and resource markets (e.g. Lane-Miller et al. 2013), so as to maintain a focus on farmers voluntarily changing their current management practices or land use to achieve environmental

\footnotetext{
${ }^{2}$ For example, Rolfe et al. (2017) identified 96 tenders conducted in Australia between 2001 and 2012 from a search of the published and grey literature. Only 22 of those tenders in the published literature and 24 of those tenders in the grey literature have been included in this review.
} 
outcomes with a procurement auction mechanism. We note that this narrow focus is consistent with other review papers (e.g. Whitten et al. 2017; Wunscher and Wunder 2017; Lundberg et al. 2018) that have focused on payments to farmers and other landholders for the provision of conservation and ecosystem services.

The most prominent example of a conservation tender ${ }^{3}$ is the Conservation Reserve Program (CRP) in the United States, although there have been a number of issues that distinguish it from smaller schemes, as well as changes in operation over time (Hellerstein 2017). The CRP is a type of repeated reverse auction designed to retire environmentally sensitive cropland and pasture that has operated in various formats for more than 30 years, evolving from near open enrolment to competitive enrolment and then to a mixture of competitive and targeted enrolment (Kirwan et al. 2005; Hellerstein 2017). In the period to 1989 the CRP operated more like a grant program with thresholds rather than a reverse auction as virtually all offers from farmers were accepted if requested rates were below a regionally-set Maximum Acceptable Rental Rate. Even after the CRP was reformed with more emphasis on an environmental benefits index and costs, costs were only included as part of the weighting functions, and automatic re-enrolment from 2007 maintained the majority of original signups in the program (Hellerstein 2017). The Environmental Quality Incentives Program in the United States also operated in part like a conservation tender, particularly between the period 1996 and 2002 (Claassen et al. 2008).

It is difficult to estimate participation rates in the CRP because outcomes are typically reported in acreage terms, although Kirwen et al. (2005) has identified the numbers of proposals submitted. In the CRP targets are set in terms of total acreages enrolled rather than budget ceilings, with acreage capped at $25 \%$ of farmland in a county. Participants are attracted by the levels of rent in excess of costs; Kirwan et al. (2005) estimated rent premiums at between $10 \%$ and $40 \%$ of total expenditures. Bid caps are used to limit excessive rent seeking, although setting bid caps too low might reduce participation and create requirements for more expensive actions to meet acreage targets (Hellerstein 2017). In 2015 there were about 7.3 million ha enrolled under general signup arrangements broadly consistent with a reverse tender, approximately $9.1 \%$ of eligible farmland ${ }^{4}$, as well as a further 2.5 million ha under continuous signup ${ }^{5}$ (Hellerstein 2017). For the purposes of this analysis, the rate of $9.1 \%$ has been assumed to be indicative of the proportion of eligible farmers contracted, with a success rate of 85\% extrapolated from 2010 (Hellerstein 2017). A back calculation generates an approximate participation rate of $11 \%$ of eligible farmers.A summary of the 36 selected tenders is shown in Table 1, with the data sorted in descending order of participation rate and then success rate. For convenience we have condensed the observations from multiple tenders or repeat tenders into single observations, so these 36 entries actually represent 59 separate tenders that have been conducted, as well as the repeated rounds of the Conservation Reserve Program. The summary allows several conclusions to be drawn. First, participation appears to be much higher in developing countries than developed countries, although the number of tenders in developing countries is lower (8 out 36). This supports the arguments of Khalumba et al. (2014) and Wünscher and Wunder (2017) that participation in developing countries is likely to be driven by different factors compared to tenders in developed countries. A second key conclusion is that most activity in conservation tenders has been in Australia, with about $44 \%$ of the identified tenders. This supports

\footnotetext{
${ }^{3}$ The PES scheme in Costa Rica is another national scheme that has some competitive elements (Fletcher and Breitling 2012)

${ }^{4}$ An additional 39.2 million ha of cropland was deemed eligible in 1996 (Hellerstein 2017).

${ }^{5}$ In contrast Messer et al. (2017) reported that in 2015 the CRP had enrolled 365,617 farms comprising 24.3 million acres.
} 
the analysis of Rolfe et al. (2017) who identified 96 separate auctions conducted between 2001 and 2012.

The analysis raises the question of why so few conservation tenders appear to have been performed in the United States despite the extent of funding on conservation and provision of ecosystem services (Arnold et al. 2013; Wunder et al. 2018, Salzman et al. 2018). Possible reasons are that substantial activity is incorporated into the Conservation Reserve Program, that there is greater use of other market based instruments such as water quality trading (Shortle 2013) and transferable development rights (Horowitz et al. 2009; Messer and Allen 2010), and that there may be better design of direct funding programs to achieve conservation outcomes (Messer et al. 2016).

Table 1: Participation rates in selected conservation tenders (Refereed publications)

\begin{tabular}{|c|c|c|c|c|c|c|c|}
\hline Country & name /description & year & $\begin{array}{l}\text { \# of } \\
\text { auctions }\end{array}$ & $\begin{array}{l}\text { \# of } \\
\text { Participants } \\
\text { / eligible } \\
\text { bidders }\end{array}$ & $\begin{array}{l}\text { Participation } \\
\text { rate }\end{array}$ & $\begin{array}{l}\text { Success } \\
\text { rate }\end{array}$ & Source \\
\hline Indonesia & Soil conservation & 2006 & 1 & $82 / 83$ & $98.8 \%$ & $41.5 \%$ & $\begin{array}{l}\text { Jack et al 2009; Ajayi } \\
\text { et al 2012; Leimona } \\
\& \text { Carrasco } 2017 \text {; } \\
\text { McGrath et al } 2017\end{array}$ \\
\hline Malawi & Tree planting & & 1 & $433 / 472$ & $91.7 \%$ & $37.7 \%$ & Ajayi et al 2012 \\
\hline Tanzania & Tree planting & 2009 & 2 & $268 / 400$ & $67.0 \%$ & $4.6 \%$ & Jindal et al 2013 \\
\hline Bolivia & $\begin{array}{l}\text { Conserve traditional } \\
\text { quinoa varieties }\end{array}$ & 2010 & 1 & $12 / 18$ & $66.7 \%$ & $53.4 \%$ & $\begin{array}{l}\text { Narloch et al 2011, } \\
2017\end{array}$ \\
\hline Peru & $\begin{array}{l}\text { Conserve traditional } \\
\text { quinoa varieties }\end{array}$ & 2010 & 1 & $13 / 20$ & $65.0 \%$ & $42.7 \%$ & $\begin{array}{l}\text { Narloch et al 2011, } \\
2017\end{array}$ \\
\hline Australia & $\begin{array}{l}\text { Improve water quality } \\
\text { from dairy }\end{array}$ & 2006 & 1 & $14 / 28$ & $50.0 \%$ & $75.0 \%$ & $\begin{array}{l}\text { Rolfe and Windle } \\
2011\end{array}$ \\
\hline Australia & $\begin{array}{l}\text { Establish biodiversity } \\
\text { corridor }\end{array}$ & 2006 & 1 & $26 / 112$ & $23.2 \%$ & $57.7 \%$ & Rolfe et al 2011 \\
\hline Australia & $\begin{array}{l}\text { Improve water quality } \\
\text { from horticulture }\end{array}$ & 2007 & 1 & $8 / 45$ & $17.8 \%$ & $76.5 \%$ & $\begin{array}{l}\text { Rolfe and Windle } \\
2011\end{array}$ \\
\hline Australia & $\begin{array}{l}\text { Biodiversity gains and } \\
\text { water quality outcomes }\end{array}$ & 2004 & 1 & $27 / 224$ & $12.1 \%$ & $58.6 \%$ & Connor et al. 2008 \\
\hline US & $\begin{array}{l}\text { CRP - retire farmland } \\
\text { (from 1985) }\end{array}$ & & & & $\begin{array}{c}10.7 \% \\
\text { (approx.) }\end{array}$ & $\begin{array}{c}85 \% \\
(2010) \\
\end{array}$ & Hellerstein 2017 \\
\hline Nepal & $\begin{array}{l}\text { Reduce open field burning } \\
\text { of rice straw }\end{array}$ & 2010 & 1 & $317 / 3005$ & $10.6 \%$ & $52.7 \%$ & Pant 2015 \\
\hline Australia & $\begin{array}{l}\text { Improve water quality } \\
\text { from agriculture }\end{array}$ & 2007 & 1 & $58 / 695$ & $8.3 \%$ & $37.9 \%$ & $\begin{array}{l}\text { Rolfe et al.2011; } \\
\text { Rolfe. \& Windle } \\
2011\end{array}$ \\
\hline Australia & $\begin{array}{l}\text { Protect biodiversity in } \\
\text { wheatbelt }\end{array}$ & 2004 & 2 & $59 / 740$ & $8.0 \%$ & $26.1 \%$ & $\begin{array}{l}\text { Hajkowicz et al } \\
2007 ; \text { Gole et al } \\
2005\end{array}$ \\
\hline Kenya & Forest enrichment & 2009 & 3 & $114 / 1845$ & $6.2 \%$ & $6.1 \%$ & Khalumba et al 2014 \\
\hline US & $\begin{array}{l}\text { Sediment reduction } \\
\text { through BMP adoption }\end{array}$ & $\begin{array}{r}2007 \\
-8\end{array}$ & 3 & $13 / 225$ & $5.7 \%$ & $75.4 \%$ & $\begin{array}{l}\text { Smith et al 2009, } \\
2012\end{array}$ \\
\hline Canada & $\begin{array}{l}\text { Protect native grasslands } \\
\text { and wetlands in prairies }\end{array}$ & 2001 & 4 & $46 / 3665$ & $1.3 \%$ & $27.7 \%$ & Brown et al 2011 \\
\hline Germany & Conserve arable plants & 2007 & 2 & $23 / 1968$ & $1.2 \%$ & $75.7 \%$ & $\begin{array}{l}\text { Ulber et al 2011; } \\
\text { Wunder et al. } 2008 .\end{array}$ \\
\hline US & $\begin{array}{l}\text { BMP adoption to improve } \\
\text { water quality }\end{array}$ & 2014 & 2 & $10 / 1085$ & $0.9 \%$ & $80.6 \%$ & $\begin{array}{l}\text { Palm-Forster et al } \\
2016\end{array}$ \\
\hline Canada & Restore drained wetlands & 2009 & 2 & $20 / 6578$ & $0.3 \%$ & $18.3 \%$ & Hill et al 2011 \\
\hline Japan & $\begin{array}{l}\text { Improve water quality } \\
\text { from irrigation }\end{array}$ & 2011 & 1 & $177 / ?$ & & $98.5 \%$ & Takeda et al 2015 \\
\hline China & $\begin{array}{l}\text { Afforestation and land use } \\
\text { change }\end{array}$ & 2009 & 1 & $303 / ?$ & & $87.9 \%$ & Wang et al. 2012 \\
\hline
\end{tabular}




\begin{tabular}{|c|c|c|c|c|c|c|}
\hline Germany & Grasslands & 2006 & 2 & $65 / ?$ & $68 \%$ & $\begin{array}{l}\text { Klimek et al 2008, } \\
\text { Groth } 2011\end{array}$ \\
\hline Australia & Protect native vegetation & 2001 & 2 & 98/? & $65.5 \%$ & Stoneham et al 2003 \\
\hline Finland & $\begin{array}{l}\text { Apply gypsum on farms to } \\
\text { reduce phosphorus loads }\end{array}$ & 2010 & 1 & $9 / ?$ & $65.5 \%$ & Iho et al. 2014 \\
\hline Australia & $\begin{array}{l}\text { Multiple-outcome auction } \\
\text { of land use change }\end{array}$ & 2005 & 1 & $? / ?$ & $62.0 \%$ & $\begin{array}{l}\text { Eigenraam et al } \\
2007\end{array}$ \\
\hline Australia & $\begin{array}{l}\text { Biodiversity conservation } \\
\text { and salinity mitigation }\end{array}$ & 2004 & 2 & $? / ?$ & $56.8 \%$ & Whitten et al 2013 \\
\hline Australia & Salinity & 2006 & 2 & $32 / ?$ & $56.3 \%$ & Whitten et al 2013 \\
\hline Australia & $\begin{array}{l}\text { Protect biodiversity in } \\
\text { native vegetation }\end{array}$ & 2004 & 2 & $56 / ?$ & $56.3 \%$ & Whitten et al 2013 \\
\hline UK & $\begin{array}{l}\text { Grampian and Central } \\
\text { Scotland Challenge Funds }\end{array}$ & 2002 & 2 & $? / ?$ & $54.1 \%$ & $\begin{array}{l}\text { Latacz-Lohmann \& } \\
\text { Schilizzi } 2005, \\
\text { Lundberg et al } 2018\end{array}$ \\
\hline Finland & Forestry & $\begin{array}{r}2004 \\
-7 \\
\end{array}$ & 1 & $356 / ?$ & $44.3 \%$ & $\begin{array}{l}\text { Juutinen \& } \\
\text { Ollikainen (2010) }\end{array}$ \\
\hline Australia & Protect biodiversity & 2006 & 1 & $? / ?$ & $34.6 \%$ & $\begin{array}{l}\text { Windle and Rolfe } \\
2008\end{array}$ \\
\hline Australia & $\begin{array}{l}\text { Protect biodiversity in } \\
\text { native vegetation }\end{array}$ & 2005 & 3 & $97 / ?$ & $34.3 \%$ & Comerford 2013 \\
\hline US & Water buybacks in drought & 2001 & 5 & $194 / ?$ & $? / 347$ & $\begin{array}{l}\text { Cummings et al } \\
2004\end{array}$ \\
\hline Germany & Conserve arable plants & 2007 & 2 & $? / ?$ & $? / ?$ & Groth 2011 \\
\hline Australia & Salinity / forestry & 2005 & 2 & $? / ?$ & $? / ?$ & Lowell et al 2007 \\
\hline
\end{tabular}

The data reveals that many studies ( $47 \%$ of our sample) do not provide enough information to allow participation rates to be calculated. Where participation rates are available, the data reveals very low partipation rates in developed countries; of the nine studies with identified participation rates there was only one study with participation greater than $25 \%$ (a small, targeted auction in Australia), and four studies with participation around $1 \%$ or lowerParticipation rates are generally higher in developing countries, as demonstrated in Figure 2. As well, there is often an inverse relationship between participation rates and success rates, as identified in Table 1, where tenders with very low participation rates tended to have high acceptance rates. This raises concerns that there may be some form of adverse selection present, with agents forced to select more expensive bids in tenders with low participation rates.

Figure 1: Participation rates in conservation auctions in developed and developing countries 


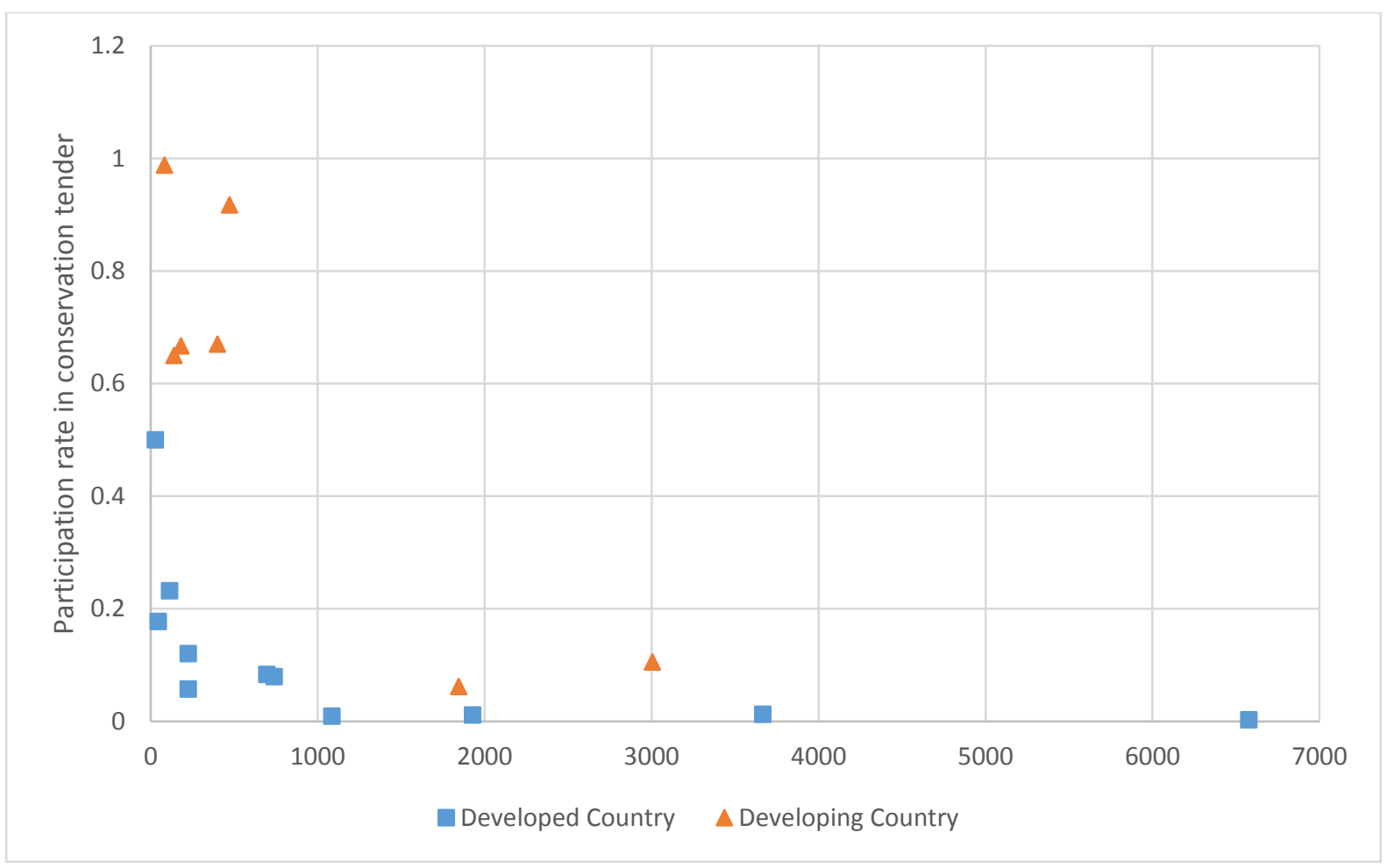

Similar findings can be identified from a sample of the grey literature, drawing on reports, book chapters and conference papers (Table 2). While this sample may not be as systematic as those identified from journal articles, it still does not capture all known surveys ${ }^{6}$. Participation rates could only be calculated for 5 of the 33 tenders, while 24 out of the 33 identified tenders were conducted in Australia.

Table 2: Participation rates in selected conservation tenders (Grey literature)

\begin{tabular}{|c|c|c|c|c|c|c|c|}
\hline Country & name /description & $\begin{array}{l}\text { year } \\
\text { (initial) }\end{array}$ & $\begin{array}{l}\text { Number } \\
\text { of } \\
\text { auctions }\end{array}$ & $\begin{array}{l}\text { \# of } \\
\text { Participants } \\
\text { / eligible } \\
\text { bidders }\end{array}$ & $\begin{array}{l}\text { Participation } \\
\text { rate }\end{array}$ & $\begin{array}{l}\text { Success } \\
\text { rate }\end{array}$ & Source \\
\hline Canada & $\begin{array}{l}\text { Improve water quality } \\
\text { and habitat }\end{array}$ & 2013 & 1 & $15 / 19$ & 0.79 & 0.21 & $\begin{array}{l}\text { Packman et al. } \\
\text { (2013). }\end{array}$ \\
\hline Canada & $\begin{array}{l}\text { Restore drained } \\
\text { wetlands }\end{array}$ & 2016 & 1 & $8 / 87$ & 0.09 & 0.93 & Kauffman (2018) \\
\hline Canada & $\begin{array}{l}\text { Restore drained } \\
\text { wetlands }\end{array}$ & 2015 & 1 & $4 / 66$ & 0.06 & 0.96 & Novak (2016) \\
\hline Australia & Catchment management & 2006 & 2 & $34 / 1041$ & 0.03 & 0.5 & $\begin{array}{l}\text { Whitten and Moir } \\
(2007)\end{array}$ \\
\hline Australia & $\begin{array}{l}\text { Ground nesting bird } \\
\text { habitat }\end{array}$ & 2008 & 1 & $17 / ?$ & & 0.87 & $\begin{array}{l}\text { Whitten et al. } \\
(2008)\end{array}$ \\
\hline Australia & Vegetation protection & 2005 & 2 & $? / ?$ & & 0.82 & Whitten et al (2012) \\
\hline Germany & Grassland conservation & 2003 & 1 & $30 / ?$ & & 0.8 & $\begin{array}{l}\text { Lacatz-Lohmann and } \\
\text { Schilizzi (2005) }\end{array}$ \\
\hline Germany & Crop retirement & 2005 & 1 & $38 / ?$ & & 0.74 & $\begin{array}{l}\text { Lacatz-Lohmann and } \\
\text { Schilizzi (2005); } \\
\text { Groth (2005) }\end{array}$ \\
\hline US & water buyback & 2003 & 2 & $16 / ?$ & & 0.72 & $\begin{array}{l}\text { Hartwell and } \\
\text { Aylward (2007) }\end{array}$ \\
\hline Australia & Vegetation protection & 2011 & 2 & $? / ?$ & & 0.63 & Whitten et al (2012) \\
\hline
\end{tabular}

${ }^{6}$ For example, a further 50 tenders in Australia were identified by Rolfe et al. (2017). 


\begin{tabular}{|l|l|c|c|c|c|c|l|}
\hline Australia & Vegetation protection & 2006 & 2 & $63 / ?$ & & 0.62 & $\begin{array}{l}\text { O'Connor et al } \\
\text { (2008) }\end{array}$ \\
\hline Australia & Wetlands and habitat & 2006 & 5 & $? / ?$ & & 0.61 & Whitten et al (2012) \\
\hline US & $\begin{array}{l}\text { Improve water quality } \\
\text { and habitat }\end{array}$ & 2005 & 2 & $? / ?$ & & 0.61 & $\begin{array}{l}\text { Greenhalgh et al. } \\
(2007)\end{array}$ \\
\hline Australia & $\begin{array}{l}\text { Biodiversity } \\
\text { conservation }\end{array}$ & 2004 & 2 & $37 / ?$ & & 0.57 & $\begin{array}{l}\text { Whitten et al 2012; } \\
\text { Miles 2008 }\end{array}$ \\
\hline Australia & Vegetation protection & 2009 & 2 & $? / ?$ & & 0.56 & O'Connor et al 2012 \\
\hline Australia & River protection & 2010 & 2 & $? / ?$ & & 0.5 & Whitten et al 2012 \\
\hline Australia & Vegetation protection & 2009 & 1 & $9 / ?$ & & 0.45 & O'Connor et al 2013 \\
\hline Australia & Forest protection & 2006 & 2 & $? / ?$ & & $?$ & $\begin{array}{l}\text { Masden Jacob } \\
\text { Associates 2010b }\end{array}$ \\
\hline & & & & & & ? & $\begin{array}{l}\text { Marsden Jacob } \\
\text { Associates 2010a }\end{array}$ \\
\hline
\end{tabular}

These low rates of participation in conservation auctions do not appear to be limited to the agricultural-environmental settings. In the fishing vessel buyback auctions reported by Schilizzi and Latacz-Lohmann (2012), 198 licence holders out of 607 participated in 2001 and 159 out of 478 participated in 2003, giving participation rates of 33\% in both cases. DePiper (2015) reports 492 bids for crab pot buybacks in Maryland from 3,676 eligible licences, representing a participation rate of 13\%, while Holzer et al. (2017) report little participation in tenders for fishing licence buybacks in Maryland.

\section{DRIVERS OF PARTICIPATION: THE ADOPTION PERSPECTIVE}

One way of understanding low participation rates in conservation tenders is to view participation as an adoption issue; this is the approach taken in most analyses to date. The roots for this lie in an extensive body of literature on adoption drivers for improving best practices in agriculture (e.g. Prokopy et al., 2008, Baumgart-Getz et al., 2012), which has then developed to explain landholders' adoption of more environmentally sustainable practices (e.g. Pannell et al., 2006, Knowler and Bradshaw, 2007). In addition a literature has developed around drivers of involvement in environmental initiatives and agri-environmental schemes (e.g. Siebert et al., 2006, Burton et al., 2008, Hanley et al., 2012, Raggi et al., 2015, Unay-Gailhard and Bojnec 2016, de Krom, 2017); and more recently, a focus on drivers of involvement in market-based instruments such as tenders and trading schemes (Morrison et al., 2011, Whitten et al., 2013, Blackmore and Doole, 2013, Motallebi et al., 2016, Bond et al. 2017).

The literature on adoption drivers for more sustainable farming practices is rich but not necessarily consistent. For example, four major review studies identified very different drivers of successful adoption: Pannell et al., (2006) classified the drivers into two broad groups: those relating to social, cultural and personal factors, and those relating to the practices themselves; Prokopy et al., (2008) identified education levels, capital, income, farm size, access to information, positive environmental attitudes, environmental awareness, and utilization of social networks; Baumgart-Getz et al., (2012). identified access to and quality of information, financial capacity, and being connected to agency or local networks of landholders or watershed groups; while Knowler and Bradshaw (2007) found that there were few if any variables that consistently predicted adoption once a variety of case study and contextual factors were controlled for.

The literature on drivers of participation in agri-environmental program schemes is also rich and varied. These involve decisions to adopt a sustainable farming practice as well as to be involved in a funding program, so participation in these may be more complex than decisions to just change 
farming practices. Many studies (e.g. Defranceso et al., 2008) have identified the importance of financial drivers to explain adoption in agri-environmental schemes. This aligns with the economic concept of 'missing markets' that is often used to explain why landholders do not automatically provide environmental services, and supports a theoretical justification for paying landholders to provide ecosystem services (Hanley et al. 2012). Sierbert et al., (2006) reviewed about 160 studies on landholder participation in biodiversity policies, identifying that financial and economic incentives are important but not the only drivers of participation.

Non-financial drivers of participation in agri-environmental schemes are regularly identified as important. Socio-demographic, cultural and human capital drivers of participation have been identified in many studies (Lynch and Lovell, 2003, Langpap and Wu, 2004, Defrancesco et al., 2008, Hynes and Garvey, 2009, Morrison et al., 2011), with factors such as age, education, environmental attitudes, human capital (including previous participation and knowledge and skills), attitudes to risk and peer group attitudes commonly identified. Social capital has been identified as a key factor underpinning participation (Mathijs, 2003, de Krom, 2017, Morrison et al., 2011), as have institutional factors (Mettepenningen et al., 2011, Mettepenningen et al., 2013, Taylor and Van Grieken, 2015), in part because these improve trust and positive attitudes and reduce transaction costs.

While there are fewer studies of participation drivers in conservation tenders, most have identified similar elements as being important. Non-financial drivers have been identified as participation factors by Moon and Cocklin (2011) Moon et al., (2012), Morrison et al., (2011) and Comerford (2013). Morrison et al., (2011) found that human capital and social capital factors were important to explain participation in market based instruments in Australia, while Blackmore and Doole (2013) identified landholder attitudes and skills as important, together with some program design factors such as contract length, engagement and information.

There is some evidence that landholders with off-farm income, commonly termed lifestyle landholders, are more likely to participate in conservation tenders in part because of their capacity to offset risk in reduced profits with off-farm income (Comerford 2013). Those who participate may already have strong pro-environmental attitudes and better knowledge of the environmental issues (Moon et al., 2012, Blackmore and Doole, 2013, Doole et al., 2014, Blackmore et al., 2014). Similarly Bond et al. (2017) identify that non-traditional farmers (e.g. absentee owners) can be important sources of participation. In the BushTender program in Australia, it was found that landholders were more likely to participate if they were environmentally aware (signified by membership of an environmental organisation) and if they operated relatively less intensive agricultural enterprises (Stoneham et al., 2003).

Finally there may be aspects of what is required of landholders in the particular environmental program that affects their adoption decision. For example, the practice of restoring drained or impacted wetland basins in agricultural lands has been found to be a particularly unappealing activity for landholders (e.g. Hill et al., 2011, Kauffman 2018). Thus, low participation rates may be related to attitudes, opinions or the presence of social norms around the particular ecological asset in question or what kind of practice change is required of landholders. The perception that the new practices are undoing previous policies (e.g. drainage of wetlands and, in Australia, land clearing history) may also generate frustration and opposition. It is also possible that conservation tenders have been preferentially deployed where practice change is difficult or undesirable to landholders and where an approach inviting price-setting has been used as a method of inducing participation. 


\section{DRIVERS OF PARTICIPATION: THE COMPLEXITY OF THE AUCTION PROCESS.}

A second pathway to understanding low participation rates in conservation tenders is to focus on the auction process and identify where particular design factors may have positive or negative impacts on participation. Conservation tenders are primarily used to address problems of asymmetric information (one party holds more information than the other) and the complexity involved in purchasing environmental improvements from private landholders, where governments or other program managers do not know the private costs of management change and landholders are not aware of public preferences for conservation (Latacz-Lohmann and van der Hamsvoort 1997, Ferraro 2008). The standard theoretical basis for conservation tenders lies in auction theory (LataczLohmann and Van der Hamsvoort, 1997, Latacz-Lohmann and Van der Hamsvoort, 1998, Cason and Gangadharan, 2004), and in particular in procurement auction theory (Laffont and Tirole, 1990).

The key stages of a conservation tender scheme involves auction design, design of bid selection metrics and contract design, where auction design targets the performance of the actual auction, bid design targets the evaluation of bids submitted, and contract design targets the operation and enforcement of the contracts once successful bids have been selected. These three stages are complicated by the varying possible interactions with participants, where knowledge gaps, learning effects, strategic behaviour, reactions to risk and uncertainty, social norms, perverse incentives and rent seeking are potential issues that have to be considered. Additional heterogeneity is introduced by differences in the environmental assets, opportunity costs and the types of improvements sought by the auction agency. These factors mean there are a great number of potential variations in the design, implementation and performance of conservation tenders that make it difficult in practice to develop an ideal tender.

Tenders can be designed in different ways, with key options including choices between budgetconstrained or target constrained auctions, discriminatory or uniform pricing, single or multiple rounds of bidding, and individual versus group bids (Latacz-Lohmann and Van der Hamsvoort, 1997, Milgrom, 2004, Stoneham et al., 2003, Cason and Gangadharan, 2004). However theoretical conditions and assumptions underpinning auction design often do not hold in real world situations, so conservation tenders often present very different design and implementation challenges compared to other auction mechanisms (Whitten et al., 2017). Typically the management issue of focus is on the periphery of landholder knowledge and interests. In addition, payments can comprise a small proportion of enterprise budgets and landholders may have low levels of understanding about some aspects of costs, such as restoration costs (Iftekhar et al., 2017). As well landholders have limited knowledge and experience about the tender process that will be followed and the type and level of competition they will face. This means that there are often issues for the auction designers to tailor the tender mechanism to the situation, for the agencies to encourage participation, and for landholders to construct bids and understand the process (Whitten et al., 2013).

Whitten et al., (2013) review barriers to participation in conservation tenders across a number of dimensions and propose a five-stage framework covering alignment, opportunity, engagement, contracting and post-participation factors. Engagement covers a number of processes, including communication about a programme, helping participants to design tenders, and dealing with unsuccessful bids. In contrast to studies identifying individual and social factors, Whitten et al., (2013) focused more on characteristics of the tender process to explain participation, identifying alignment of management priorities, opportunities for payment, effective engagement, and clear and uncomplicated bidding and contracting rules as being essential. 
One distinguishing difference in the literature, compared to participation in more traditional agrienvironmental schemes, is more focus on transaction costs as a barrier to landholder participation in tender processes (e.g. McCann and Easter, 1999, McCann and Claassen, 2016, Falconer, 2000, Blackmore and Doole, 2013, Whitten et al., 2013, Comerford, 2013, Palm-Forster et al., 2016). Transaction costs occur for both buyers and sellers, and include the search, negotiation and administration costs of finding, organising and completing contracts, as well as the costs of dealing with complex conservation contracts with complicated ecological goals (Hanley et al., 2012, Whitten et al., 2017). There is evidence that high transaction costs limit participation, particularly for risk averse bidders (Palm-Forster et al., 2016) and those who have only a small area of land to offer, which supports the development of strategies to reduce complexity and improve engagement and information.

Strong relationship between landholders and auctioning agencies may underpin positive support for constructing bids. These features have been identified as important in limiting transaction costs and increasing participation (Blackmore and Doole, 2013, Blackmore et al., 2014, Doole et al. 2014).

Conservation tenders which had a simple and clear application process, along with simple monitoring of outcomes, lowered the transaction costs and increased participation of landholders (Morrison et al., 2011). Another approach to reduce transaction costs and levels of uncertainty in bid formation involves holding multiple rounds within an auction, as this provides a price discovery process and limits concerns of winner's curse (Rolfe et al., 2009, Hill et al., 2010, Comerford 2013, Boxall et al., 2017).

Another difference in the literature between traditional agri-environmental schemes and competitive tenders is more attention given to bid formation issues in tenders (Holzer et al., 2017, Whitten et al., 2017). Real world situations are much more complex than formal models that assume landholders have full knowledge of their costs and revenues and zero transaction costs to engage in tenders (Whitten et al., 2017). This means that landholders who understand and are able to estimate expected changes in profits and costs with some confidence may be more likely to participate in a conservation auction as they have less risk of experiencing the winner's curse. Others, who have a limited understanding of the management practices proposed and how these will impact their costs and their subsequent profits, may be less likely to participate (Palm-Forster et al., 2016).

Landholder perception of the likelihood of success in being selected has been highlighted as a key determinant of participation in conservation tenders (Whitten et al., 2017). Closely aligned to this are attitudes to and perceptions of risks (Hellerstein et al., 2015, Whitten et al., 2013, Whitten et al., 2017, Hellerstein, 2017, Palm-Forster et al., 2016) including outcome risks and errors in estimating management costs. Factors such as complexity, contract conditions and contract length impact on how landholders assesses their opportunity costs in regards to risk, particularly weather and market risk over longer contract terms, as well transaction costs in proportion to opportunity costs (Whitten et al., 2013, Palm-Forster, 2016; Hellerstein et al., 2017, Whitten et al., 2017). Landholders are not necessarily risk-neutral, and heterogeneity in risk attitudes may explain variations in participation (Latacz-Lohmann and van der Hamsvoort 1997, Whitten et al., 2017). Experience in auction settings may reduce perceptions of risk and transaction costs, leading to higher participation rates. 


\section{MODELS OF PARTICIPATION}

The factors identified in the previous two sections encourage us to develop some formal models of participation for landholders where we attempt to distinguish between a hierarchy of decisions to (a) adopt an environmental management practice, (b) engage in an agri-environmental scheme or (c) participate in a conservation tender. This contrasts with the standard economic approach of simply assuming that landholders make each of these decisions on the basis of 'consolidated' expected net benefits.

Latacz-Lohmann and Van der Hamsvoort (1997) introduced a model of optimal bidding behaviour where farmers were assumed to participate if the utility from participating outweighed the reservation utility, which is the return from having a rejected bid. Like other models of auction and bidding processes, theirs can involve a number of simplifying assumptions about risk preferences, transaction costs and independence of values, among others, as the focus of most applications is to identify the most suitable auction and bid process, and to measure efficiencies. Typical of earlier focuses, Latacz-Lohmann and Van der Hamsvoort (1997) treat the participation choice by farmers as a one-step process where the farmer evaluates the expected utility from submitting a bid. This remains the underlying model in most analysis of conservation tenders and experimental auctions (Schilizzi and Latacz-Lohmann 2007, 2016, Schilizzi 2017), where the default assumptions are that participants are striving to maximise their utility and make integrated decisions about participation and bid formation.

However not all models of participation in conservation tenders or broader agri-environmental schemes have used the economic lens of utility maximisation to predict behaviour. A number of behavioural models have also been employed. Unay-Gailhard and Bojnec (2016) (see also Morrison et al. 2011, Defrancesco et al. 2008 and Hynes and Garvey 2009) summarise the literature explaining participation in PES schemes by several behavioural model approaches, including: the theory of diffusion and adoption of innovation, the social network approach, the theory of planned behaviour, and contract theory (incorporating principal-agent relationships). A key motivation underpinning the application of these models is a focus on understanding and changing behaviour in the longer term (Unay-Gailhard and Bojnec 2016).

Models of participation have also been developed by analysing participation decisions, either through surveys of farmers who have participated in tenders (e.g. Morrison et al. 2011, Blackmore and Doole 2013), panel data analysis of agricultural enterprises that have different characteristics and participation in agri-environmental schemes (e.g. Hynes and Garvey 2009, Zimmerman and Britz 2016), or applying experiments to farmers about their future choices if a conservation tender was to be offered (e.g. Greiner 2016). Whitten et al. (2013) develop a 'barriers and opportunities' framework to explain participation, involving the five key steps mentioned earlier of alignment, opportunity, engagement, contracting and post-participation. A common theme in these 'realistic' models is that program, landholder and enterprise characteristics are very important in explaining participation in conservation tender programs.

In this analysis we develop a more unified model of participation that goes beyond a simple utility maximisation framework to include considerations of the type of auction, the stages in decision making, and varying program, farmer and enterprise factors. We begin by classifying conservation tenders into three main groups by purpose, as this has implications for the types of issues and costs involved:

- Natural asset tenders (type N), which involve the reservation of existing natural areas or assets from farming operations. Examples include tenders to protect native bushland or 
reserve some areas from farming (e.g. Stoneham et al. 2003), as would be purchases of water rights or other natural inputs into farming operations.

- $\quad$ Supplementary asset tenders (type S), which involve remediation of natural assets. Examples include tenders to stop farming wetlands and actively restore them back to natural conditions (e.g. Hill et al., 2011, Boxall et al., 2017).

- $\quad$ Changes to farming systems (type F), which typically involve changes to management practices to reduce harmful impacts on environmental assets. Examples include tenders to reduce pollutants or losses of ecosystem services (e.g. Rolfe et al., 2011, Boxall et al., 2013).

Landholders who are approached to participate in a tender for one of these types of actions need to make a series of decisions about the nominated practice change, potential involvement with a government or funding agency, and the bidding process. Here we summarise those decisions as a logical set of sequential choices, noting that the order of choices may be confounded in real life applications.

The first layer of choice that landholders make is about whether they would make the desired management change or decide to adopt a new practice. This involves identifying the tradeoffs involved, as follows:

$\operatorname{Adopt}($ Yes $/$ No $)=f\left(\left(\Delta\right.\right.$ Revenue $_{\mathrm{PC}}-\Delta$ CostS $_{\mathrm{PC}}-\Delta$ Costs $\left._{\mathrm{C}}\right), \mathrm{LH}_{\mathrm{PC}}$, Farm $_{\mathrm{PC}}$, Innovation $\left.{ }_{\mathrm{PC}}\right)$

Where:

- $\quad \Delta$ Revenue include changes in gross revenue (excluding any incentive payment)

- $\Delta$ Costs $_{P C}$ include changes in operating costs

- $\Delta$ Costs $_{C}$ include changes in capital costs

- $\quad \mathbf{L H}$ includes landholder factors such as attitudes, age, education, experience and knowledge of the innovation

- $\quad$ Farm includes farm and enterprise factors, including farm size, profitability and debt levels

- Innovation includes characteristics of the new practice, including risk and trialability, noting that there may be endogeneity with other factors, and

- $\quad$ PC represents practice change.

This model represents a partial equilibrium framework for a landholder considering an enterprise change, where the key factor will be whether additional revenue from the practice change outweighs additional costs, taking into account landholder, farm and practice change factors. The economic tradeoffs will vary by the type of practice change. For the subset of $\mathrm{N}, \mathrm{S}$ and $\mathrm{F}$ changes that we are interested in, $\mathrm{N}$ is likely to involve some marginal changes in revenue and production costs (because natural areas may not be very productive), $\mathrm{S}$ will involve losses to revenue as well as higher capital costs (as remediation is normally expensive), and $\mathrm{F}$ will involve both changes to revenue and production costs, as well as potential capital costs, to achieve changes in farm management.

Extending this to agri-environmental schemes introduces a second stage in the decision process, the decision to participate in a type of principal-agent relationship. Landholders now have to make two choices: the decision to adopt and the decision to participate. The choices are nested; landholders 
can adopt without participating, but cannot participate without adoption. Typically agrienvironmental schemes apply to actions with negative private returns, where the incentive payment or subsidy offered is presumably sufficient to at least compensate for the net opportunity cost (the difference between changes in revenue and changes in costs). The decision to participate in an agrienvironmental scheme over the two stages can be represented in the following way:

ParticipateAE(Yes/No) $=f($ Payment $-\mathrm{TC}), \mathrm{LH}_{\mathrm{AE}}$, Farm $_{\mathrm{AE}}$, Mechanism $\left._{\mathrm{AE}}\right)$,

contingent on

Adopt(Yes/No $)=f\left(\left(\Delta\right.\right.$ Revenue $_{\mathrm{PC}}-\Delta \operatorname{Costs}_{\mathrm{PC}}-\Delta \operatorname{Costs}_{\mathrm{C}} \mathrm{LH}_{\mathrm{PC}}$, Farm $\mathrm{PC}$, Innovation $\mathrm{PC}_{\mathrm{PC}}$

Where:

- $\quad$ Payment is the direct incentive paid through the agri-environmental scheme

- $\quad T C$ are the transaction costs associated with participation in the scheme

- Mechanism represents the type of funding program and how it is implemented (i.e. the rules around involvement and delivery)

- $\quad \boldsymbol{A E}$ refers to a particular agri-environmental scheme.

In this situation, the net financial benefits to a landholder from adoption and participation are the sum of the opportunity costs from adoption ( $\Delta$ Revenue $_{\mathrm{PC}}-\Delta$ Costsp $_{\mathrm{PC}}-$ Costsc $_{\text {) }}$ ) and net returns from participation (Payment -TC). Typically the payment has to be at least sufficient to cover farm opportunity costs and transaction costs.

Notable differences from a single adoption decision are that (a) there is now a two-stage decision process, (b) net benefits are more complex to estimate, (c) there are additional interactions with landholder characteristics, (d) there are additional interactions with farm characteristics, and (e) the type of mechanism and design may influence landholder choices. There may also be some impacts on the adoption decision: positive influences include positive reinforcement of attitudes, networking and better information, while negative influences may include reduced options for trialability and reversibility because of program requirements. This is represented by the subscript on Mechanism in Equation 2.

The same approach can be used to represent the decision to participate in a conservation tender instead of a different type of agri-environmental scheme, with an additional extension. In a conservation auction, the landholder not only has to decide (a) whether to adopt and (b) whether to participate, but also has to (c) set the bid price, where there may be a two-way relationship between their bid price and participation. The bid price incorporates some economic rent (profit) which makes the option more attractive than 'business as usual'. This can be represented in the following way:

Bid $=f($ NetCostsAdopt + NetCostsPartic + Profit $)$, Expect $_{\mathrm{CT}}$, Comp $\left._{\mathrm{CT}}\right)$,

contingent on

Participate ${ }_{C A}($ Yes $/$ No $)=f($ Payment $-T C)$, LH $_{C T}$, Farm $_{C T}$, Mechanism $\left.C_{C T}\right)$, and

$\operatorname{Adopt}($ Yes/No $)=f\left(\left(\Delta\right.\right.$ Revenue $_{\mathrm{PC}}-\Delta$ CostSPC $_{\mathrm{P}}-\Delta$ Costs $)+\mathrm{LH}_{\mathrm{PC}}+$ Farm $_{\mathrm{PC}}+$ Innovation $\left._{\mathrm{PC}}\right) \ldots($ (3)

Where: 
- $\quad$ Bid is the amount of direct incentive (payment) nominated by the landholder

- NetCostsAdopt are the net financial and non-financial costs of adopting the relevant action

- NetCostsPartic includes costs of participating in the process, including transaction costs,

- $\quad$ Profit represents the extent of surplus of bid-shading required (influenced by factors such as landholder attitudes, enterprise viability, the funding pool and competition pressures),

- $\quad$ Expect represent the landholder's assessment of a bid being successful,

- $\quad$ Comp represents the perceived competition in a tender, and

- $\quad \boldsymbol{C T}$ refers to a conservation tender.

This formulation would suggest that the bid amount should be at least equal to landholder perceptions of the expected costs of adoption and participation, plus some additional profit (bidshading or information rent) that provides the incentive to change from current arrangements. The bid amounts are also likely to be influenced by landholder characteristics, where attitudes towards uncertainty and other factors may influence perceptions of costs and revenues. Expectations of success and competitive pressures have opposite influences on bid amounts; bidders will tend to ask for higher rents if they are more confident of success, and lower amounts if faced with greater levels of competition. There may be some cases where landholders perceive that they will receive other benefits from participating, such as learning effects or altruistic benefits, which would reduce the amount of direct incentive required.

Moving to a conservation auction instrument also has implications for the participation choices ${ }^{7}$. Mechanism design is particularly relevant to participation in conservation tenders, as evidenced by the substantial literature about how auction design and contract design issues impact on participation, efficiency and performance (Whitten et al. 2013, 2017). Landholder and farm characteristics can also be important drivers (and inhibitors) of participation in conservation tenders as compared to broader agri-environmental schemes (Morrison et al., 2011; Blackmore and Doole, 2013, Blackmore et al., 2014, Doole et al. 2014), while the way that conservation tradeoffs are framed and communicated to landholders can directly influence participation in tender mechanisms (Kusmanoff et al. 2016).

In a further step, greater realism about participation choices can be generated by allowing for uncertainty (Wichmann et al. 2017). In reality, landholders may not know the financial outcomes of a practice change because of variations in weather, input and output markets, production functions and environmental responses, let alone the extent of transaction costs, the extent of competition and likelihood of success in the tender. Each of these may be more appropriately represented by a distribution of potential outcomes, overlaid by heterogeneity in environmental targets, as well as farm and landholder characteristics. This can be shown as follows, where perceived risks associated with a conservation tender impact the decision to adopt (Riskspc), the decision to be involved in a program (Risks ${ }_{\mathrm{CT}}$ ), and the risks of setting the bid level (Risks ${ }_{\mathrm{BID}}$ ). The landholder choice can then be represented as three simultaneous and interlinked decisions:

Bid $=f\left(\right.$ Expected Profit, Expect $_{\mathrm{CT}}$, Comp $_{\mathrm{CT}}$, Risk $\left._{\mathrm{BID}}\right)$, and

Participate CA $_{\text {(Yes/No }}=f($ Payment $-\mathrm{TC})$, LH $_{\mathrm{CT}}$, Farm $_{\mathrm{CT}}$, Mechanism $_{\mathrm{CT}}$, Risks $_{\mathrm{CT}}$, and

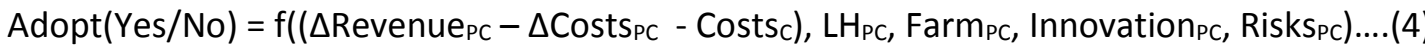

\footnotetext{
${ }^{7}$ These are now subscripted $\mathrm{CT}$ instead of AE to reflect this change.
} 
Note that Expected Profit consolidates the revenues and costs across the three stages, as the amount of profit (or bid shading) is equal to the bid amount less the net costs of adopting the changed practice and the net costs of participating in the tender process and being involved with an agency or government.

In decisions to adopt and participate, uncertainty about the returns and costs of a new practice introduce the problem of the 'winner's curse', where a successful bid increases the risk of negative returns because revenues or costs have not been estimated accurately (see Wichmann et al. 2017). Uncertainty about outcomes, as in Schilizzi \& Latacz-Lohmann (2016), together with risk-averse behaviour by landholders, may be among the key reasons for slow adoption of many practices. It is worth noting that in a conservation tender this influence is compounded by contractual arrangements that lock landholders into specific arrangements. Additional uncertainty about the transactions costs involved and the impact of changes on farm and enterprise operations will add to the risks of conservation tenders.

This framework provides a guide to categorising the literature around factors that impact on participation in agri-environmental schemes, and in particular, conservation tenders. Whitten et al. (2013) focus on mechanism issues in their review of key factors affecting adoption, although their 'alignment' and 'adoptability' elements are related to how easy it is for farmers to make practice changes. In contrast, Palm-Forster et al. (2016) focus on transaction costs as the key factor that limits participation. DePiper (2015) notes that participation rates can be low and bids can be substantially above an individual's true valuation, which is consistent with risks and transaction costs, among other factors, impacting on bid and participation choices. Some studies have noted that participation and bids seem to increase with experience and familiarity with the auction mechanism (Messer et al. 2017).

The framework also provides some insights into the adverse selection problem identified by Arnold et al. (2013). Conservation auctions (and agri-environmental schemes in general) are targeted at landholders who would not normally consider changing their management because opportunity costs or other factors constrain adoption. Yet participation is more likely when adoption is easy; this leads to an adverse selection problem where many entrants into a program would do the actions without the introduction of an incentive program. The challenge in an auction design process is to generate participation for projects that would not otherwise be adopted (sometimes referred to as 'additionality') while minimising costs and maximising benefits.

Recognising risk and uncertainty in a tender process allows for more complex behaviour by participants (Schilizzi and Latacz-Lohmann 2012; 2016). Wichmann et al. (2017) note that participants in a conservation tender have to balance out the risks of setting their bids too high and missing out in the auction against the risks of setting bids too low and not being able to cover costs (in situations where there is uncertainty around costs). Participants may also be uncertain about transaction costs and competition pressures, creating complex interrelationships between the three parts of the decision process. Depending on levels of risk aversion and other factors such as costs of bidding, participants may make different decisions about participation and bid levels.

\section{DISCUSSION AND CONCLUSIONS}

The model of participation developed in this paper sets out why participation choices in conservation tenders are complex, and demonstrates that piecemeal explanations are probably not appropriate. We make three important contributions to the literature on this topic, as well as 
providing a comprehensive review of the relevant literature. First, we document low participation in tenders, particularly across developed countries. Second, we explain that a decision to participate in a conservation tender involves three linked decisions about whether to change a management practice, whether to be involved in a public program with contractual responsibilities, and how to set a price or bid. These may be viewed as hierarchical decisions, although there is no clear evidence of the sequences in how landholders process these choices. Third, we explain that there are a number of factors that affect each stage of the decision process, with some factors such as landholder attitudes and risk considerations relevant to all three. This illustrates that decisions to participate in a conservation tender are more complex than simple adoption choices described in the literature.

We summarise the factors influencing participation in Figure 2, capturing the background case study factors, as well as the key decision stages of practice change, involvement and bid setting.

\section{Figure 2: Drivers of participation in conservation tenders}

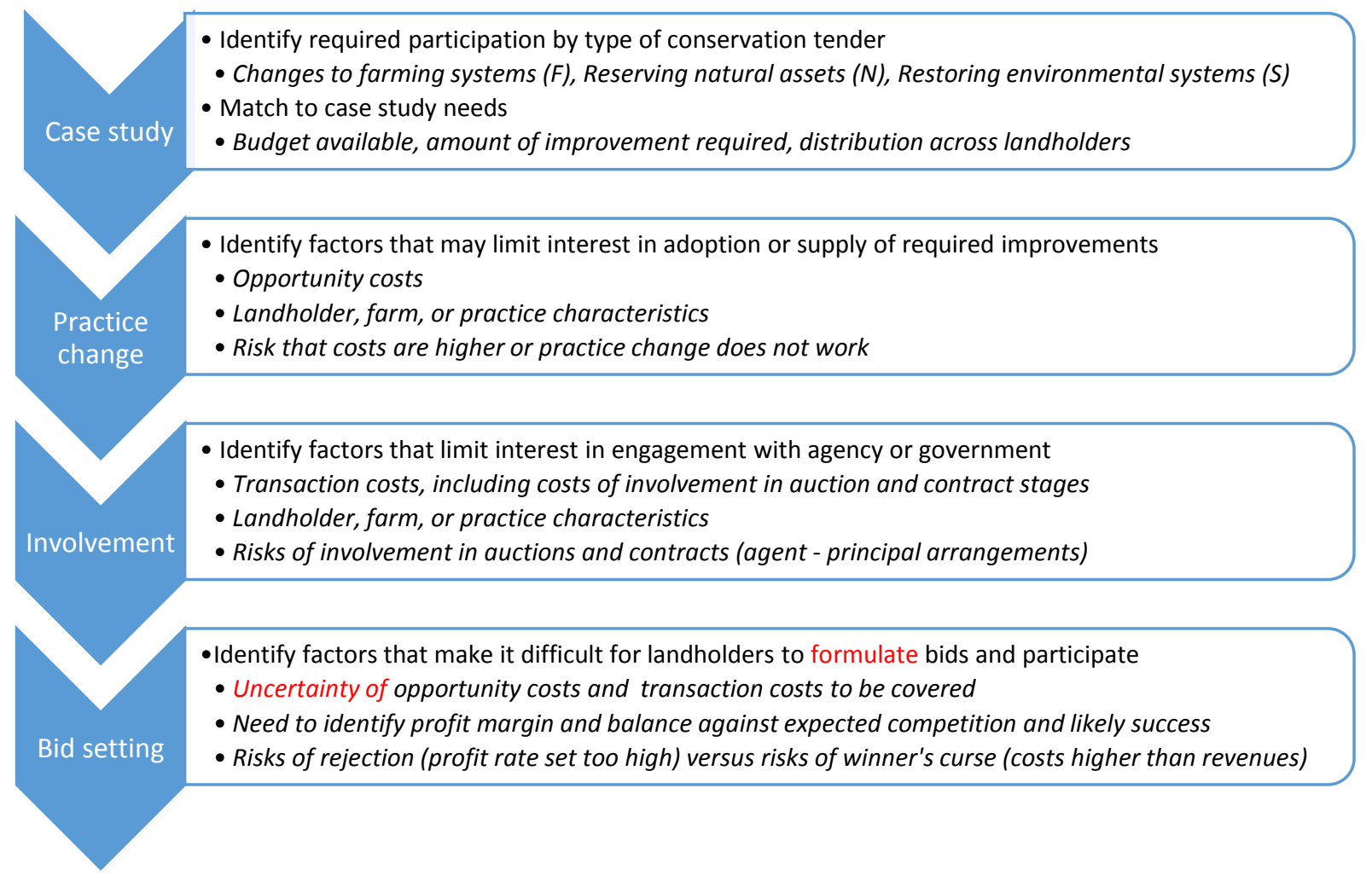

There are several important implications of this framework to highlight. The first is that what is an "appropriate" level of participation varies by the type of conservation tender; those focused on changes to farming systems (F) are more likely to require higher participation than tenders focused on reserving natural assets $(\mathrm{N})$ or restoring environmental systems $(\mathrm{S})$. Requirements may also vary by costs, where S-type and F-type tenders involve more cost components than $\mathrm{N}$-type tenders, thus making the price discovery process more important to policy analysts. They may also relate to the desired magnitude of the management changes required by the auctioning agency. Many schemes are focused on the quantity of environmental change that can be achieved, particularly S-type and Ftype tenders. Where these can be achieved by engaging the larger land management operations in the policy application region then requirements for participation become more specialised. In situations where high participation rates are required, conservation tenders may not be suitable as a policy mechanism to generate environmental change. 
A second implication is that participation choices may be represented as complex combinatorial decision problems, where landholders need to evaluate the proposed actions and contractual arrangements, estimate their revenues and costs of adoption and engagement, consider entering into a principal-agent arrangement, factor in the risks and uncertainties of the various elements, and consider the competitive processes in the auction. Those influences will vary by case study setting and the types of environmental assets involved, so that drivers of participation may not be systematically consistent across many auction frameworks (Whitten et al., 2017).

Complexity across the different stages of the decision process may explain why participation in conservation tenders is low. This includes complexity around the economic factors, where landholders have to estimate the potential changes in revenues and costs across the different stages and then form their bid, and complexity around non-economic factors, which influences landholders' willingness to engage. Uncertainty about factors such as costs, competition and the likelihood of bid success may also drive non-participation. Understanding how landholders view, combine and process different elements of costs and risks associated with conservation tenders is likely to be critical to understanding participation decisions, and remains an important topic for future research. Identifying the critical factors of complexity that most affect participation will help identify program design changes that would simplify the decision processes for landholders.

\section{REFERENCES}

AJAYI, O.C., JACK, B.K. \& LEIMONA, B. 2012. Auction design for the private provision of public goods in developing countries: Lessons from payments for ecosystem services in Malawi and Indonesia. World Development, 40, 1213-1223.

ARNOLD, M.A., DUKE, J.M. \& MESSER, K.D. 2013. Adverse selection in reverse auctions for ecosystem services, Land Economics, 89, 387-412.

BAUMGART-GETZ, A., PROKOPY, L. S. \& FLORESS, K. 2012. Why farmers adopt best management practice in the United States: A meta-analysis of the adoption literature. Journal of Environmental Management, 96, 17-25.

BLACKMORE, L., DOOLE, G. \& SCHILIZZI, S. 2014. Practitioner versus participant perspectives on conservation tenders. Biodiversity and conservation, 23, 2033-2052.

BLACKMORE, L. \& DOOLE, G. J. 2013. Drivers of landholder participation in tender programs for Australian biodiversity conservation. Environmental Science \& Policy, 33, 143-153.

BOND, A.J., O'CONNOR, P.J. \& CAVAGNARO, T.R. 2017. Who participates in conservation incentive programs? Absentee and group landholders are in the mix. Land Use Policy, 72, 410-419.

BOSKOVIC, B. \& NOSTBAKKEN, L. 2017. The cost of endangered specie protection: Evidence from auctions for natural resources, Journal ofEnvironmental Economics and Management, 81, 174-192.

BOXALL, P.C., PERGER, O. \& WEBER, M. 2013. Reverse auctions for agri-environmental improvements: Bid selection rules and pricing for beneficial management practice adoption. Canadian Public Policy 39(s2): 23-36.

BOXALL, P. C., PERGER, O., PACKMAN, K. \& WEBER, M. 2017. An experimental examination of target based conservation auctions. Land Use Policy, 63, 592-600.

BROWN, L. K., TROUTT, E., EDWARDS, C., GRAY, B. \& HU, W. 2011. A uniform price auction for conservation easements in the Canadian prairies. Environmental and Resource Economics, $50,49-60$.

BURTON, R., KUCZERA, C. \& SCHWARZ, G. 2008. Exploring farmers' cultural resistance to voluntary agri-environmental schemes. Sociologia ruralis, 48, 16-37. 
CLAASSEN, R., CATTANOE, A. \& HOHANSSON, R. 2008. Cost-effective design of agri-environmental payment programs: U.S. experience in theory and practice. Ecological Economics, 65, 737752.

CONNOR, J.D., WARD, J.R. \& BRYAN, B. 2008. Exploring the cost effectiveness of land conservation auctions and payment policies. Australian Journal of Agricultural and Resource Economics, 42: 303-319.

CASON, T. N. \& GANGADHARAN, L. 2004. Auction design for voluntary conservation programs. American Journal of Agricultural Economics, 86, 1211-1217.

COMERFORD, E. 2013. The impact of permanent protection on cost and participation in a conservation programme: A case study from Queensland. Land use policy, 34, 176-182.

COMERFORD, E. 2014. Understanding why landholders choose to participate or withdraw from conservation programs: A case study from a Queensland conservation auction. Journal of environmental management, 141, 169-176.

CUMMINGS, R.G., HOLT, C.A. \& LAURY, S.K. 2004. Using laboratory experiments for policymaking: An example from the Georgia Irrigation Reduction Auction. Journal of Policy Analysis and Management, 23, 341-363.

DE KROM, M. P. 2017. Farmer participation in agri-environmental schemes: Regionalisation and the role of bridging social capital. Land Use Policy, 60, 352-361.

DEFRANCESCO, E., GATTO, P., RUNGE, F. \& TRESTINI, S. 2008. Factors Affecting Farmers' Participation in Agri-environmental Measures: A Northern Italian Perspective. Journal of Agricultural Economics, 59, 114-131.

DEPIPER, G.S., HIGGINS, N., LIPTON, D. \& STOCKING, A. 2013. Auction design, incentives and buying back Maryland and Virginia crab licenses, Canadian Journal of Agricultural Economics, 61, 353-370.

DEPIPER, G. S. 2015. To Bid or Not to Bid: The Role of Participation Rates in Conservation Auction Outcomes. American Journal of Agricultural Economics, 97, 1157-1174.

DOOLE, G. J., BLACKMORE, L. \& SCHILIZZI, S. 2014. Determinants of cost-effectiveness in tender and offset programmes for Australian biodiversity conservation. Land Use Policy, 36, 23-32.

EIGENRAAM, M., STRAPPAZZON, L., LANSDELL, N., BEVERLY, C. \& STONEHAM, G.C. 2007. Designing frameworks to deliver unknown information to support market-based instruments. Agricultural Economics, 37 (S1), 261-269.

FALCONER, K. 2000. Farm-level constraints on agri-environmental scheme participation: a transactional perspective. Journal of Rural Studies, 16, 379-394.

FERRARO, P. J. 2008. Asymmetric information and contract design for payments for environmental services. Ecological Economics, 65, 810-821.

FLETCHER, R. \& Breitling, J. 2012. Market mechanism or subsidy in disguise? Government payment for environmental services in Costa Rica. Geoforum, 43, 402-411.

GOLE, C., BURTON, M., WILLIAMS, K. J., CLAYTON, H., FAITH, D. P., WHITE, B., HUGGETT, A. \& MARGULES, C. 2005. Auction for landscape recovery: final report. WWF-Australia, Sydney, 191.

GREENHALGH, S., GUILING, J., SELMAN, M. and ST JOHN, J. (2007). Paying for Environmental Performance: Using Reverse Auctions to Allocate Funding for Conservation, Policy Note: Paying for Environmental Performance, World Resources Institute.

GREINER, R. 2015. Factors influencing farmers' participation in contractual biodiversity conservation: a choice experiment with northern Australian pastoralists. Australian Journal of Agricultural and Resource Economics, 60, 1-21.

GROTH, M. 2005. Ausschreibungen in einem Konzept zur ergebnisorientierten Honorierung ökologischer Leistungen - Eine transaktionskostenökonomische Analyse. Paper at the 45th annual conference of the German Agricultural Economics Society (GEWISOLA), Göttingen, Germany, October 2005. 
GROTH, M. 2011. Cost-effective biodiversity conservation: Procurement auctions and payment-byresults. EuroChoices, 10(2), 32-37.HAJKOWICZ, S., HIGGINS, A., WILLIAMS, K., FAITH, D.P. \& BURTON, M. 2007. Optimisation and the selection of conservation contracts. Australian Journal of Agricultural and Resource Economics, 51, 39-56.

HANLEY, N., BANERJEE, S., LENNOX, G. D. \& ARMSWORTH, P. R. 2012. How should we incentivize private landowners to 'produce' more biodiversity? Oxford Review of Economic Policy, 28, 93-113.

HARTWELL, R. and AYLWARD, B. 2007. Auctions and the reallocation of water rights in central Oregon, Deschutes River Conservancy River Papers.

HAYNES, D., BRODIE, J., WATERHOUSE, J., BAINBRIDGE, Z., BASS, D. \& HART, B. 2007. Assessment of the Water Quality and Ecosystem Health of the Great Barrier Reef (Australia): Conceptual Models. Environmental Management, 40, 993-1003.

HELLERSTEIN, D., HIGGINS, N. A. \& ROBERTS, M. 2015. Options for improving conservation programs: Insights from auction theory and economic experiments. ERR-181, U.S. Department of Agriculture, Economic Research Service, January 2015.

HELLERSTEIN, D. M. 2017. The US Conservation Reserve Program: The evolution of an enrollment mechanism. Land Use Policy, 63, 601-610.

HILL, M.R.J., MCMASTER, G., HARRISON, T., HERSHMILLER, A. \& PLEWS, T. 2011. A reverse auction for wetland restoration in the Assiniboine River watershed, Saskatchewan. Canadian Journal of Agricultural Economics, 59, 245-258.

HOLZER, J., DEPIPER, G. \& LIPTON, D. 2017. Buybacks with costly participation. Journal of Environmental Economics and Management, 85, 130-145.

HOROWITZ, J.K., LYNCH, L. \& STOCKING, A. 2009. Competition-based environmental policy: An analysis of farmland preservation in Maryland, Land Economics, 85, 555-575.

HYNES, S. \& GARVEY, E. 2009. Modelling Farmers' Participation in an Agri-environmental Scheme using Panel Data: An Application to the Rural Environment Protection Scheme in Ireland. Journal of Agricultural Economics, 60, 546-562.

IFTEKHAR, M. S., HAILU, A. \& LINDNER, R. K. 2014. Does It Pay to Increase Competition in Combinatorial Conservation Auctions? Canadian Journal of Agricultural Economics/Revue canadienne d'agroeconomie, 62, 411-433.

IFTEKHAR, M. S., POLYAKOV, M., ANSELL, D., GIBSON, F. \& KAY, G. M. 2017. How economics can further the success of ecological restoration. Conservation Biology, 31, 261-268.

IHO, A., LANKOSKI, J., OLLIKAINEN, M., PUUSTINEN, M. \& LEHTIMAKI, J. 2014. Agri-environmental auctions for phosphorus load reduction: Experiences from a Finnish pilot. Australian Journal of Agricultural and Resource Economics, 58, 205-222.

JACK, B. K. 2013. Private Information and the Allocation of Land Use Subsidies in Malawi. American Economic Journal: Applied Economics, 5, 113-35.

JACK, B.K., LEIMONA, B. \& FERRARO, P.J. 2009. A revealed preference approach to estimating supply curves for ecosystem services: Use of auctions to set payments for soil erosion control in Indonesia. Conservation Biology, 23, 359-367.

JINDAL, R., KERR, J.M., FERRARO, P.J. \& SWALLOW, B.M. 2013. Social dimensions of procurement auctions for environmental service contracts: Evaluating tradeoffs between costeffectiveness and participation by the poor in rural Tanzania. Land Use Policy, 31, 71-80.

JUUTINEN, A. \& OLLIKAINEN, M. 2010. Conservation contracts for forest biodiversity: Theory and experience from Finland, Forest Science, 56, 201-2011.

KAUFFMAN, A.M. 2018. Investigating the use Reverse Auctions for Restorable Wetlands on the Prairies. Unpublished MSc. Thesis, Dept of Resource Economics and Environmental Sociology, University of Alberta.

KHALUMBA, M., WÜNSCHER, T., WUNDER, S., BÜDENBENDER, M. \& HOLM-MÜLLER, K. 2014. Combining Auctions and Performance-Based Payments in a Forest Enrichment Field Trial in Western Kenya. Conservation biology, 28, 861-866. 
KIRWEN, B., LUBOWSKI, R.N. \& ROBERTS, M.J. 2005. How cost-effective are land retirement auctions? Estimating the difference between payments and willingness to accept in teh Conservation Reserve Program, American Journal of Agricultural Economics, 87, 1239-1247

KLIMEK, S., RICHTER gen KEMMERMANN, A., STEINMANN, H.-H., FREESE, J. \& ISSELSTEIN, J. 2008. Rewarding farmers for delivering vascular plant diversity in managed grasslands: A transdisciplinary case-study approach, Biological Conservation, 141, 2888-2897.

KNOWLER, D. \& BRADSHAW, B. 2007. Farmers' adoption of conservation agriculture: A review and synthesis of recent research. Food policy, 32, 25-48.

KUSMANOFF, A.M., HARDY, M.J., FIDLER, F., MAFFEY, G., RAYMOND, C., REED, M.S., FITZSIMONS, J.A. \& BEKESSY, S.A. 2016. Framing the private land conservation conversation: Strategic framing of the benefits of conservation participation could increase landholder engagement. Environmental Science and Policy, 61, 124-128.

LAFFONT, J.-J. \& TIROLE, J. 1990. Adverse selection and renegotiation in procurement. The Review of Economic Studies, 57, 597-625.

LALATACZ-LOHMANN, U. \& SCHILIZZI, S. 2005. Auctions for conservation contracts: a review of the theoretical and empirical literature: Report to the Scottish Executive Environment and Rural Affairs Department.

LANE-MILLER, C.C., WHEELER, S., BJORNLUND, H. \& CONNOR, J. 2013. Acquiring Water for the Environment: Lessons from Natural Resources Management, Journal of Environmental Policy \& Planning, 15, 513-532.

LANGPAP, C. \& WU, J. 2004. Voluntary conservation of endangered species: when does no regulatory assurance mean no conservation? Journal of Environmental Economics and Management, 47, 435-457.

LATACZ-LOHMANN, U. \& SCHILIZZI, S. 2005. Auctions for Conservation Contracts: A Review of the Theoretical and Empirical Literature. Report to the Scottish Executive Environment and Rural Affairs Department.

LATACZ-LOHMANN, U. \& VAN DER HAMSVOORT, C. 1997. Auctioning Conservation Contracts: A Theoretical Analysis and an Application. American Journal of Agricultural Economics, 79, 407418.

LATACZ-LOHMANN, U. \& VAN DER HAMSVOORT, C. P. C. M. 1998. Auctions as a Means of Creating a Market for Public Goods from Agriculture. Journal of Agricultural Economics, 49, 334-345.

LEIMONA, B. \& CARRASCO, L.R. 2017. Auction winning, social dynamics and non-compliance in a payment for ecosystem services scheme in Indonesia. Land Use Policy, 63, 632-644.

LOWELL, K., DROHAN, J., HAJEK, C., BEVERLY, C. \& LEE, M. 2007. A science-driven market-based instrument for determining the cost of environmental services: A comparison of two catchments in Australia. Ecological Economics, 64, 61-69.

LUNDBERG, L., PERSSON, U.M., ALPIZAR, F. \& LINDGREN, K. 2018. Context matters: Exploring the cost-effectiveness of fixed payments and procurement auctions for PES. Ecological Economics, 146, 347-358.

LYNCH, L. \& LOVELL, S. J. 2003. Combining spatial and survey data to explain participation in agricultural land reservation programs. Land Economics, 79, 259-276.

MA, S., SWINTON, S. M., LUPI, F. \& JOLEJOLE-FOREMAN, C. 2012. Farmers' Willingness to Participate in Payment-for-Environmental-Services Programmes. Journal of Agricultural Economics, 63, 604-626.

MARSDEN JACOB ASSOCIATES (MJA), 2010a. Review of the Environmental Stewardship Program. Report prepared for the Department of Sustainability, Environment, Water, Population and Communities. Canberra.

MARSDEN JACOB ASSOCIATES (MJA), 2010b. The Tasmanian Forest Conservation Fund and associate programs: purpose, performance and lessons. Report prepared for the Department of Sustainability, Environment, Water, Population and Communities. Canberra. 
MATHIJS, E. 2003. Social capital and farmers' willingness to adopt countryside stewardship schemes. Outlook on agriculture, 32, 13-16.

MCCANN, L. \& CLAASSEN, R. 2016. Farmer transaction costs of participating in federal conservation programs: magnitudes and determinants. Land Economics, 92, 256-272.

MCCANN, L. \& EASTER, K. W. 1999. Transaction costs of policies to reduce agricultural phosphorous pollution in the Minnesota River. Land Economics, 402-414.

MCGRATH, F.L., CARRASCO, L.R. \& LEIMONA, B. 2017. How auctions to allocate payments for ecosystem services contracts impact social equity. Ecosystem Services, 25, 44-55.

MESSER, K.D. 2007. Transferable development rights programs: An economic framework for success. Journal of Conservation Planning, 3, 47-56.

MESSER, K.D. \& ALLEN, W.L. 2010. Applying optimization and the analytic hierarchy process to enhance agricultural preservation strategies in the State of Delaware, Agricultural and Resource Economics Review, 39, 442-456

MESSER, K.D., DUKE, J.M., LYNCH, L. \& LI, T. 2017. When Does Public Information Undermine the Efficiency of Reverse Auctions for the Purchase of Ecosystem Services? Ecological Economics, 134, 212-226.

MESSER, K.D., KECINSKI, M., TANG, X. \& HIRSCH, R.H.IV. 2016. Multiple-Knapsack optimisation in land conservation: Results from the first cost-effective conservation program in the United States. Land Economics, 92, 117-130.

METTEPENNINGEN, E., BECKMANN, V. \& EGGERS, J. 2011. Public transaction costs of agrienvironmental schemes and their determinants-Analysing stakeholders' involvement and perceptions. Ecological Economics, 70, 641-650.

METTEPENNINGEN, E., VANDERMEULEN, V., DELAET, K., VAN HUYLENBROECK, G. \& WAILES, E. J. 2013. Investigating the influence of the institutional organisation of agri-environmental schemes on scheme adoption. Land Use Policy, 33, 20-30.

MILES, C., 2008. Testing market based instruments for conservation in northern Victoria. In Lefroy, T., Bailey, K., Unwin, G. and Norton, T. (eds) Biodiversity: Integrating Conservation and Production. CSIRO Publishing, Canberra,

MILGROM, P. R. 2004. Putting auction theory to work, Cambridge University Press.

MOON, K. \& COCKLIN, C. 2011. Participation in biodiversity conservation: motivations and barriers of Australian landholders. Journal of Rural Studies, 27, 331-342.

MOON, K., MARSHALL, N. \& COCKLIN, C. 2012. Personal circumstances and social characteristics as determinants of landholder participation in biodiversity conservation programs. Journal of environmental management, 113, 292-300.

MORRISON, M., OCZKOWSKI, E. \& GREIG, J. 2011. The primacy of human capital and social capital in influencing landholders' participation in programmes designed to improve environmental outcomes. Australian Journal of Agricultural and Resource Economics, 55, 560-578.

MOTALLEBI, M., O'CONNELL, C., HOAG, D. \& OSMOND, D. 2016. Role of Conservation Adoption Premiums on Participation in Water Quality Trading Programs. Water, 8, 245.

NARLOCH, U., DRUCKER, A.G. \& PASCUAL, U. 2017. What role for cooperation inconservation tenders? Paying farmer groups in the High Andes. Land Use Policy 63, 659-671.

NARLOCH, U., PASCUAL, U. \& DRUCKER, A. 2011. Cost-effectiveness targeting under multiple conservation goals and equity considerations in the Andes. Environmental Conservation, 38, 417-425.

NOVAK, L. 2016. A Reverse Auction for Wetland Restoration in Southern Alberta. Unpublished MSc. Thesis Dept of Resource Economics and Environmental Sociology, University of Alberta.

O'CONNOR, P., MORGAN, A. \& BOND, A. 2008. BushBids: Biodiversity Stewardship in the Eastern Mount Lofty Ranges, South Australia. Government of South Australia, Adelaide.

O'CONNOR, P., BOND, A., MORGAN, A., LAWLEY, V. \& SAISON, C. 2012. River Bend BushBids: Conservation along the River Murray and surrounding plains of the South Australian MurrayDarling Basin. Government of South Australia, Adelaide. 
O'CONNOR, P.J., SAISON, C., MORGAN, A., BOND, A. \& LAWLEY, V. 2013. Southern Mallee BushBids: Conservation in the Southern Murray Mallee Districts of the South Australian Murray-Darling Basin. Government of South Australia, Adelaide.

PACKMAN, K., WEBER, M. \& CUTLAC, M. 2013. Dennis Lake Conservation Auction, Alberta Innovates Technology Futures.

PALM-FORSTER, L. H., SWINTON, S. M., LUPI, F. \& SHUPP, R.S. 2016a. Too burdensome to bid: Transaction costs and pay-for-performance conservation. American Journal of Agricultural Economics, 98, 1314-1333.

PALM-FORSTER, L. H., SWINTON, S. M., REDDER, T. M., DEPINTO, J. V. \& BOLES, C. M. W. 2016b. Using conservation auctions informed by environmental performance models to reduce agricultural nutrient flows into Lake Erie. Journal of Great Lakes Research, 42, 1357-1371.

PANT, K.P. 2015. Uniform-price reverse auction for estimating the costs of reducing open-field burning of rice residue in Nepal. Environmental and Resource Economics, 62, 567-581.

PANNELL, D., MARSHALL, G. R., BARR, N., CURTIS, A., VANCLAY, F. \& WILKINSON, R. 2006. Understanding and promoting adoption of conservation practices by rural landholders. Australian Journal of Experimental Agriculture, 46, 1407-1424.

PRIMMER, E., 2017. Institutional constraints on conservation auction:organizational mandate, competencies and practices. Land Use Policy, 63,621-631,

PROKOPY, L. S., FLORESS, K., KLOTTHOR-WEINKAUF, D. \& BAUMGART-GETZ, A. 2008. Determinants of agricultural best management practice adoption: Evidence from the literature. Journal of Soil and Water Conservation, 63, 300-311.

RAGGI, M., VIAGGI, D., BARTOLINI, F. \& FURLAN, A. 2015. The role of policy priorities and targeting in the spatial location of participation in Agri-Environmental Schemes in Emilia-Romagna (Italy). Land Use Policy, 47, 78-89.

ROLFE, J., GREINER, R., WINDLE, J. \& HAILU, A. 2011. Testing for allocation efficiencies in water quality tenders across catchments, industries and pollutants: a north Queensland case study*. Australian Journal of Agricultural and Resource Economics, 55, 518-536.

ROLFE, J., WHITTEN, S. \& WINDLE, J. 2017. The Australian experience in using tenders for conservation. Land Use Policy, 63, 611-620.

ROLFE, J. \& WINDLE, J. 2011. Using auction mechanisms to reveal costs for water quality improvements in Great Barrier Reef catchments in Australia. Agricultural Water Management, 98, 493-501.

ROLFE, J., WINDLE, J. \& MCCOSKER, J. 2009. Testing and implementing the use of multiple bidding rounds in conservation auctions: a case study application. Canadian Journal of Agricultural Economics/Revue Canadienne d'Agroeconomie, 57, 287-303.

SALZMAN, J., BENNETT, G., CARROLL, N., GOLDSTEIN, A. \& JENKINS, M. 2018. The global status and trends of Payments for Ecosystem Services, Nature Sustainability, 1, 136-144.

SCHILIZZI, S. 2017. An overview of laboratory research on conservation auctions. Land Use Policy, 63, 572-583.

SCHILIZZI, S. \& LATACZ-LOHMANN, U. 2007. Assessing the Performance of Conservation Auctions: An Experimental Study. Land Economics, 83, 497.

SCHILIZZI, S. \& LATACZ-LOHMANN, U. 2012. Evaluating conservation auctions with unknown bidder costs: The Scottish Fishing Vessel Decommissioning Program. Land Economics, 88, 658-673.

SCHILIZZI, S. \& LATACZ-LOHMANN, U. 2016. Incentivizing and Tendering Conservation Contracts: The Trade-off between Participation and Effort Provision. Land Economics, 92, 273-291.

SHORTLE, J. 2013. Economics and environmental markets: Lessons from water-quality trading. Agricultural and Resource Economics Review 42, 57-74.

SIEBERT, R., TOOGOOD, M. \& KNIERIM, A. 2006. Factors affecting European farmers' participation in biodiversity policies. Sociologia ruralis, $46,318-340$. 
SMITH, C.M, LEATHERMAN, J.C., PETERSON, J.M., CRESPI, J.M. \& ROE, J.D. 2012. BMPs for sale! Implications from a case study in BMP auctions, Journal of Regional Analysis and Policy, 42, 151-161.

SMITH, C.M., NEJADHASHEMI, A.P. \& LEATHERMAN, J.C. 2009. Using a BMP auction as a tool for the implementation of conservation practices, Journal of Extension, 47, 1-10.

STONEHAM, G., CHAUDHRI, V., HA, A. \& STRAPPAZZON, L. 2003. Auctions for conservation contracts: an empirical examination of Victoria's BushTender trial. Australian Journal of Agricultural and Resource Economics, 47, 477-500.

TAYLOR, B. M. \& VAN GRIEKEN, M. 2015. Local institutions and farmer participation in agrienvironmental schemes. Journal of Rural Studies, 37, 10-19.

TAKEDA, M., TAKAHASHI, D. \& SHOBAYASHI, M. 2015. Collective action vs. conservation auction: Lessons from a social experiment of a collective auction of water conservation contracts in Japan. Land Use Policy, 46, 189-200.

ULBER, L., KLIMEK, S., STEINMANN, H., ISSELSTEIN, J. \& GROTH, M. 2011. Implementing and evaluating the effectiveness of a payment scheme for environmental services from agricultural land. Environmental Conservation, 38, 464-472.

UNAY-GAILHARD, I. \& Bojnec, S. 2016. Sustainable participation behaviour in agri-environmental measures. Journal of Cleaner Production, 138, 47-58.

WANG, X., BENNETT, J., XU, J. \& ZHANG, H. 2012. An auction scheme for land use change in Sichuan Province, China. Journal of Environmental Planning and Management, 55, 1269-1288.

WHITTEN, S., GORDDARD, R., KNIGHT, A., REESON, A. \& STEVENS, D. 2008. Designing and testing an outcome focused conservation auction: evidence from a field trial targeting ground nesting birds, 10th annual BioEcon conference, Cambridge UK, September 28-30.WHITTEN, S. and MOIR, R. 2007. A review of the performance of Wimmera CMA's Catchment Tender rounds 1 and 2, Wimmera Catchment Management Authority and CSIRO, Australia.

WHITTEN, S. M., WÜNSCHER, T. \& SHOGREN, J. F. 2017. Conservation tenders in developed and developing countries - status quo, challenges and prospects. Land Use Policy, 63, 552-560.

WHITTEN, S. M., REESON, A., WINDLE, J. \& ROLFE, J. 2013. Designing conservation tenders to support landholder participation: A framework and case study assessment. Ecosystem Services, 6, 82-92.

WHITTEN, S., ZAMMIT, C., LANGSTON, A., DOERR, V., BURNS, E, DOERR, E. \& ATTWOOD, S., 2012. Money for nothing or payments for biodiversity? Design and performance of the Australian Government's Environmental Stewardship Program conservation tender metric. Paper presented at the 14th annual BioEcon conference, Cambridge, UK.

WICHMANN, B., BOXALL, P.C., WILSON, S. \& PERGER, O. 2017. Auctioning risky conservation contracts, Environmental and Resource Economics, 68, 1111-1144.WINDLE, J. \& ROLFE, J. 2008. Exploring the efficiencies of using competitive tenders over fixed price grants to protect biodiversity in Australian rangelands. Land Use Policy, 25, 388-398.

WINDLE, J., ROLFE, J., MCCOSKER, J. \& LINGARD, A. 2009. A conservation auction for landscape linkage in the southern Desert Uplands, Queensland. The Rangeland Journal, 31, 127-135.

WUNDER, S., ENGEL, S. \& PAGIOLA, S. 2008. Taking stock: A comparative analysis of payments for ecosystem services programs in developed and developing countries. Ecological Economics, 65, 834-852.

WUNDER, S., BROUWER, R., ENGEL, S., EZZINE-DE-BLAS, D., MURADIAN, R., PASCUAL, U. \& PINTO, R. 2018. From principles to practice in paying for nature's services, Nature Sustainability, 1 , $145-150$.

WÜNSCHER, T. \& WUNDER, S. 2017. Conservation tenders in low-income countries: Opportunities and challenges. Land Use Policy, 63, 672-678.

ZAMMIT, C. 2013. Landowners and conservation markets: Social benefits from two Australian government programs. Land Use Policy, 31, 11-16. 
ZIMMERMAN, A. \& BRITZ, W. 2016. European farms' participation in agri-environmental measures. Land Use Change, 50, 214-228. 